2003s-06

\title{
Company Flexibility, the Value of Management and Managerial Compensation
}

\author{
Peter Christoffersen, Andrey Pavlov
}

\section{Série Scientifique \\ Scientific Series}

\author{
Montréal \\ Février 2003
}

(C) 2003 Peter Christoffersen, Andrey Pavlov. Tous droits réservés. All rights reserved. Reproduction partielle permise avec citation du document source, incluant la notice (C).

Short sections may be quoted without explicit permission, if full credit, including $@$ notice, is given to the source.
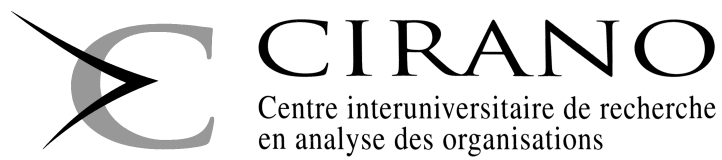

Centre interuniversitaire de recherche en analyse des organisations 


\section{CIRANO}

Le CIRANO est un organisme sans but lucratif constitué en vertu de la Loi des compagnies du Québec. Le financement de son infrastructure et de ses activités de recherche provient des cotisations de ses organisationsmembres, d'une subvention d'infrastructure du ministère de la Recherche, de la Science et de la Technologie, de même que des subventions et mandats obtenus par ses équipes de recherche.

CIRANO is a private non-profit organization incorporated under the Québec Companies Act. Its infrastructure and research activities are funded through fees paid by member organizations, an infrastructure grant from the Ministère de la Recherche, de la Science et de la Technologie, and grants and research mandates obtained by its research teams.

\section{Les organisations-partenaires / The Partner Organizations}

PARTENAIRE MAJEUR

. Ministère des Finances, de l'Économie et de la Recherche [MFER]

PARTENAIRES

. Alcan inc.

. Axa Canada

. Banque du Canada

. Banque Laurentienne du Canada

. Banque Nationale du Canada

. Banque Royale du Canada

. Bell Canada

. Bombardier

. Bourse de Montréal

. Développement des ressources humaines Canada [DRHC]

. Fédération des caisses Desjardins du Québec

. Gaz Métropolitain

. Hydro-Québec

. Industrie Canada

. Pratt \& Whitney Canada Inc.

. Raymond Chabot Grant Thornton

. Ville de Montréal

. École Polytechnique de Montréal

. HEC Montréal

. Université Concordia

. Université de Montréal

. Université du Québec à Montréal

. Université Laval

. Université McGill

ASSOCIÉ AU :

. Institut de Finance Mathématique de Montréal (IFM²)

. Laboratoires universitaires Bell Canada

. Réseau de calcul et de modélisation mathématique $\left[\mathrm{RCM}^{2}\right]$

. Réseau de centres d'excellence MITACS (Les mathématiques des technologies de l'information et des systèmes complexes)

Les cahiers de la série scientifique (CS) visent à rendre accessibles des résultats de recherche effectuée au CIRANO afin de susciter échanges et commentaires. Ces cahiers sont écrits dans le style des publications scientifiques. Les idées et les opinions émises sont sous l'unique responsabilité des auteurs et ne représentent pas nécessairement les positions du CIRANO ou de ses partenaires.

This paper presents research carried out at CIRANO and aims at encouraging discussion and comment. The observations and viewpoints expressed are the sole responsibility of the authors. They do not necessarily represent positions of CIRANO or its partners. 


\title{
Company Flexibility, the Value of Management and Managerial Compensation*
}

\author{
Peter Christoffersen ${ }^{\dagger}$, Andrey Pavlov ${ }^{\ddagger}$
}

\begin{abstract}
Résumé / Abstract
La variation dans les compensations des gestionnaires à travers les pays et les industries pour des compagnies de taille comparable est ahurissante. Nous analysons ce phénomène dans le cadre d'un modèle de compagnie en temps continu, dans lequel l'environnement économique évolue de manière stochastique et les changements dans le fonctionnement de la compagnie sont coûteux. L'idée sousjacente est que les gestionnaires dans différents pays et industries sont rémunérés de manière très différente non pas parce que leurs compétences diffèrent de manière substantielle mais plutôt parce que la valeur ajoutée par la gestion diffère substantiellement. Si les coûts d'ajustement sont peu élevés ou si l'environnement économique est relativement volatile, alors le potentiel de valeur ajoutée par la gestion active est important. La relation positive entre la volatilité de l'environnement économique et la valeur de la gestion suggère une interprétation du gestionnaire en termes d'option réelle : la gestion active peut être vue comme une option réelle sur un changement dans le plan de production. Notre modèle montre que plus l'économie est volatile, plus l'option a de valeur.
\end{abstract}

Mots clés : Variation des rémunérations des directeurs d'entreprises, coûts d'ajustement de production, volatilité des prix des facteurs de production, options réelles.

The variation in managerial compensation across countries and industries for firms of similar size is staggering. We analyze this phenomenon in a continuous time model of the firm, where the economic environment evolves stochastically over time and where changes to the firm operations are costly. The underlying idea is that managers in different countries and industries are compensated very differently, not necessarily because their skills differ substantially, but rather because the scope for management to add value to the firms varies substantially. If adjustment costs are low, or if the economic environment is relatively volatile, then the potential value-added from active management is larger. The positive relationship between economic environment volatility and the value of management suggests a real options interpretation of the manager: Active management can be viewed as a real option to make changes in the production plan. Our model shows that the higher the volatility of the economy, the larger the value of this real option.

Keywords: CEO Pay Variation, Production Adjustment Costs, Input Price Volatility, Real Options.

\footnotetext{
* We would like to thank Marcel Boyer and Pierre Lasserre for helpful discussion, and FCAR, IFM2, RCM2, and SSHRC for financial support. Any remaining errors are ours alone.

$\dagger$ Faculty of Management, McGill University, 1001 Sherbrooke Street W., Montreal, Quebec, Canada H3A 1G5. Phone: (514) 398-2869. Fax: (514) 398-3876. Email: Peter.Christoffersen@ McGill.ca.

¥ Corresponding author: Faculty of Business Administration, 8888 University Dr., Burnaby, BC, Canada, V5A 1S6.

Phone: (604) 291-5835. Fax: (604) 291-4920. Email: apavlov@sfu.ca.
} 


\section{Motivation}

The variation in managerial compensation across countries is staggering. The Worldwide Total Remuneration Report 2001-2002 by Towers Perrin reports an estimated total CEO pay ranging $\$ 287,000$ in New Zeeland to \$1.9 million in the US for an industrial company with $\$ 500$ million in annual revenues (see Figure 1). When considering non-OECD countries the variation is even larger. Similarly, Conyon and Murphy (2000) find that US executives earned twice that of their UK counter-parties in 1997 after controlling for firm size, sector and other firm characteristics. ${ }^{1}$ The variation across industries within the US is of the same order of magnitude. Murphy (1999) reports a median CEO pay of $\$ 1.5$ million in the utilities sector versus $\$ 4.6$ million in the financial services industry for S\&P500 companies in 1996.

Both the existing literature and some common sense arguments suggest a number of explanations for this disparity. Perhaps the most common one relates to the cost of living and the quality of life in general. This theory simply suggests that the higher compensation in some countries reflects the higher cost of living. Abowd and Kaplan (1999), among others, address this potential explanation and show that the CEO pay in various OECD countries varies substantially even after adjusting for purchasing power parity exchange rates (see Figure 2).

Yet another potentially credible explanation is that CEOs in high-income countries are paid more simply because everybody in those countries is paid more. While this is a very appealing argument supported by anecdotal evidence, Figures 3 and 4 show that the midlevel manager pay and the manufacturing operatives pay are substantially less variable across countries then the CEO compensation. The international compensation puzzle thus largely appears to be a CEO phenomenon.

Like any other compensation issue, the international variation in $\mathrm{CEO}$ pay has to explicitly consider taxes. It is conceivable that the variation in CEO pay is due to different taxation and the after-tax income is comparable. In Figure 5 we report the aftertax CEO pay in 1996, which also varies greatly across countries. The international variation in CEO pay is clearly not explained by differences in tax rates.

\footnotetext{
${ }^{1}$ See also Conyon and Schwalbach (1997), Kaplan (1994), Kaplan (1997), and Main et al (1994).
} 
Finally, the variation in CEO pay is consistent through time. For example, Figure 6 reports after tax-pay in 1988. Comparing this to Figure 5 we find no evidence that the CEO pay across countries is converging over time.

The compensation puzzle becomes even more intriguing when one considers the widespread phenomenon that the CEOs in the largest companies around the World tend to go to the same business schools in North America and Europe. Taking this feature to the extreme, we can consider managers across countries and industries to have roughly the same skills, yet they get paid very differently.

These findings lead one to consider the possibility that the variation in CEO compensation may arise from the varying business environments in different industries and countries. Traditional models of managerial compensation largely rely on principleagent settings, where the manager extracts rents from the company owners' inability to observe managerial effort.

The principle-agent models are useful for many purposes, but they do not appear to gain insight into the cross-country and cross-industry variation in managerial compensation. It is hard to imagine that principle-agent problems are so much worse in the US than in New Zeeland that they explain a six-fold difference in managerial compensation for similar-size companies. The principle-agent literature is surveyed in Murphy (1999).

Another strand of the literature on managerial compensation studies the use of options for managerial compensation. Recent work in this area includes Cadenillas et al (2002). Our paper uses the tools from the options compensation literature but we have a drastically different focus.

We focus on the differences in the business environments in which CEOs operate, and it is therefore useful to consider the avenues through which a CEO can add value to a company. We can group these sources of value into the following broad areas:

- Expansion of market opportunities

- Investment in new products and technologies

- Managing uncertain demand

- Production management in the face of uncertain technologies

- Managing the inputs to the production 
Of these five potential sources of managerial value, only the last one is countryspecific. To the extend that product markets are fully integrated and all companies have access to the same fundamental technology, managers in all countries are able to add approximately the same value to their firms through the first four channels. Therefore, in what follows, we focus on the management of inputs to the production because this factor is the only one (of the above five) that has the potential to explain cross-country variation in management compensation.

Based on the above line of reasoning, we focus on the part of CEO compensation related to the management of the optimal composition of inputs into the production of the output of the firm. The production plan is continuously changed by the manager according to changes in the relative prices of the inputs. The scope for managing the production plan is largest in countries or industries where the input prices are the most volatile and where the adjustment costs are the smallest. Thus our model predicts that managerial compensation, for example, will be highest in countries with a low degree of unionization, and in countries with open capital markets. Implicitly, the model also predicts that if over time countries become decreasingly unionized and capital markets increasingly liberalized, then differences in CEO pay across countries should decrease.

Our paper proceeds as follows. In Section 2 we present a model of a firm in which changes in the input factors are subject to adjustment costs. We solve for the conditions, which characterize the optimal production plan. In Section 3 explicitly solve for the value of management for different levels of adjustment costs. Section 4 summarizes our findings and suggests avenues for future work.

\section{A Dynamic Model of the Firm}

As the cost of the production inputs change, it is the manager's job to adjust the inputs in order to minimize the total cost of production. Consider a Cobb-Douglas production function with capital, $K$, and labor, $L$, as the inputs: $K^{\alpha} L^{1-\alpha}$. Let $r$ and $w$ denote the cost of capital and labor per unit time, respectively. Assume further that adjustment to the inputs can be accomplished at pre-specified costs $\delta$ and $\lambda$ (proportional to the square of the change), for capital and labor, respectively. Thus, the total instantaneous cost function is: 


$$
C d t=\left(r K+w L+\delta \Delta^{2}+\lambda \Lambda^{2}\right) d t
$$

where $\Delta$ and $\Lambda$ denote the absolute change in capital and labor per unit time. We justify the increasing adjustment costs by appealing to both economic and political factors inhibiting change. Drastic increases the labor force, for example, are very costly both because access to a large number of qualified employees is limited and the training and integration costs become prohibitive. While small reductions of the labor force can be accomplished through hiring freezes or reducing the work hours, substantial decreases are very costly because of labor union and/or political considerations. Furthermore, changing the capital used in the production also becomes very costly for large changes. Small reductions, for instance, can be accommodated through depreciation or reduced maintenance. Large reductions, on the other hand, involve outright selling the physical capital stock and can result in substantial losses to the firm.

Given the adjustment costs and the stochastic input costs, the manager's job is to minimize the expected total cost subject to the production constraint:

$$
K_{t}^{\alpha} L_{t}^{1-\alpha}=1
$$

This implies the following expressions for $L$ and $\Lambda$ as functions of $\Delta$ :

$$
\begin{aligned}
& L=K^{\frac{\alpha}{\alpha-1}} \\
& \Lambda=(\Delta+K)^{\frac{\alpha}{\alpha-1}}-K^{\frac{\alpha}{\alpha-1}}
\end{aligned}
$$

The cost of capital and labor are assumed to follow the following stochastic processes:

$$
\begin{aligned}
& d r=\mu_{r} d t+\sigma_{r} d z_{r} \\
& d w=\mu_{w} d t+\sigma_{w} d z_{w}
\end{aligned}
$$


where $\left(\mu_{r}, \sigma_{r}, \mu_{w}, \sigma_{w}\right)$ are at most functions of the state variables and time. In the numerical implementation of the model we assume the process for wages has constant coefficients and the process for interest rates follows the Cox, Ingersoll, and Ross (CIR) (1985) model.

Let $V(r, w, K, t)$ denote the expected cost under the optimal policy. The Bellman principle then becomes:

$$
\begin{aligned}
& V(r, w, K, t)= \\
& \quad \min _{\Delta} E_{t}\left[\int_{t}^{t+h}\left(r K+w L+\delta \Delta^{2}+\lambda \Lambda^{2}\right) d s+V\left(r, w, K_{t+h}, t+h\right)\right]
\end{aligned}
$$

or,

$$
0=\min _{\Delta} E_{t}\left[\int_{t}^{t+h}\left(r K+w L+\delta \Delta^{2}+\lambda \Lambda^{2}\right) d s+V\left(K_{t+h}, t+h\right)-V\left(K_{t}, t\right)\right]
$$

Taking expectation results in:

$$
0=\min _{\Delta}\left[r K+w L+\delta \Delta^{2}+\lambda \Lambda^{2}+E_{t}[d V] / d t\right]
$$

Note that:

$$
d V=V_{t} d t+V_{r} d r+V_{w} d w+V_{K} d K+\frac{1}{2} V_{r r}(d r)^{2}+\frac{1}{2} V_{w w}(d w)^{2}+V_{r w} d r d w
$$

Since the evolution of $K$ is given by $d K=\Delta d t$, the variance of the change in $K$ and its covariance with $r$ and $w$ are zero and therefore not included in equation (8). Taking expectation of the evolution of $V$ gives:

$$
E[d V]=\left(V_{t}+V_{r} \mu_{r}+V_{w} \mu_{w}+V_{K} \Delta+\frac{1}{2} V_{r r} \sigma_{r}^{2}+\frac{1}{2} V_{w w} \sigma_{w}^{2}+V_{r w} \chi_{r, w}\right) d t
$$


Substituting equation (9) into the Bellman equation (7) provides the following expression:

$$
\begin{aligned}
0 & =\min _{\Delta}\left[r K+w L+\delta \Delta^{2}+\lambda \Lambda^{2}+\right. \\
& \left.+V_{t}+V_{r} \mu_{r}+V_{w} \mu_{w}+V_{K} \Delta+\frac{1}{2} V_{r r} \sigma_{r}^{2}+\frac{1}{2} V_{w w} \sigma_{w}^{2}+V_{r w} \chi_{r, w}\right]
\end{aligned}
$$

Differentiation with respect to the choice variable $\Delta$ results in the following first-order condition:

$$
0=2 \delta \Delta+\frac{2 \lambda a}{(\alpha-1)}\left((\Delta+K)^{\frac{\alpha+1}{\alpha-1}}-K^{\frac{\alpha}{\alpha-1}}(\Delta+K)^{\frac{1}{\alpha-1}}\right)+V_{K}
$$

Solving this equation provides the optimal control policy, $\Delta^{*}$. Substituting the optimal control $\Delta^{*}$ into (3) and (10) yields a partial differential equation for $V$ which we solve using a finite difference technique.

The active manager assumes that the firm will operate for a period of time $\Psi$ after the final period $T$ without active management. This implies the following terminal condition:

$$
E\left(V_{T}\right)=E\left(C_{T} \Psi\right)=\left(r_{T} K_{T}+w_{T} L_{T}\right) \Psi
$$

In other words, the total expected cost of operation for a period of time $\Psi$ is based on the levels of capital and labor employed at time $T$.

The optimization (10) is very simple in two special cases:

- if the switch among inputs is free, i.e. $\delta=\lambda=0$, or

- if the cost of switching is prohibitively high, i.e. $\delta=\lambda=\infty$.

If the cost of switching is zero, then a manager can adjust inputs instantaneously as their prices or their marginal products change. At the other extreme, if costs of switching are very high, the optimal outputs are chosen at the beginning and cannot be 
altered. In all other intermediate cases, such as those analyzed below, the model is solved numerically.

\section{Optimization Results}

We use an explicit finite difference method so solve for the optimal adjustment policy and the value of management. Table 1 lists the specific parameters utilized in the numerical solution.

Table 1: Parameters utilized in the numerical solution

\begin{tabular}{|l|l|l|}
\hline Parameter & Description & Value \\
\hline$\alpha$ & Parameter of the production function & $1 / 2$ \\
\hline mean(r) & Average long-term interest rate (CIR model) & .08 \\
\hline$\mu_{\mathrm{w}}$ & Expected wage growth rate & .02 \\
\hline$\sigma_{\mathrm{r}}$ & Volatility of interest rates (CIR) & .0854 \\
\hline$\sigma_{\mathrm{w}}$ & Volatility of wages & .08 \\
\hline$k$ & Speed of mean-reversion (CIR) & -.2339 \\
\hline$\Psi$ & $\begin{array}{l}\text { Time of firm operation with no management beyond } \\
\text { the time horizon }\end{array}$ & 2 \\
\hline$T$ & Time horizon of active management & 5 years \\
\hline Range (K/L) & Range of the capital to labor ratios considered & .3 to 4 \\
\hline Range (r) & Range of interest rates considered & .01 to .1 \\
\hline Range (w) & Range of cost of labor considered & .01 to .1 \\
\hline $\mathrm{dt}$ & Time step & $.01=$ approx. \\
& & 3 days \\
\hline
\end{tabular}

Unless noted explicitly otherwise, all figures are depicted for wage level of .08. Although the estimation is performed in the three-dimensional state space of $K / L, r$, and $w$, we can only display the solutions in two-state space and we fix the third dimension. Unless indicated otherwise, the shape of the surfaces looks very similar for all other levels of $w$ considered but not displayed. 
First we investigate the case of very large adjustment costs. If the adjustment costs are very high, only very small adjustments are optimal. Panels A and B of Figure 7 depict the total expected cost and the optimal adjustment policy, $\Delta^{*}$, as a function of the contemporaneous capital to labor ratio and interest rates for costs of adjustment $\delta$ and $\lambda$ of 100 . These can be compared with the output level, which is normalized to unity everywhere. Not surprisingly, with such large adjustment costs the optimal adjustment policy is virtually zero regardless of the starting capital and labor levels. Furthermore, the total expected costs are entirely intuitive and higher for input mixes away from the optimum.

Similarly, Panels C and D of Figure 7 depict the total expected costs and optimal adjustment policy for adjustment costs of 1 . While still fairly high, adjustment costs of 1 allow for some adjustment of the inputs. The pattern of adjustment costs is entirely intuitive. As the capital levels exceed the optimal mix, the production process switches to a more labor-intensive mode. On the other hand, as the capital levels fall below the optimal, more capital is added. For very small levels of capital, even small increases of capital lead to substantial reductions in labor, and the optimal policy is more moderate, although new capital is still added.

Next we investigate the optimal adjustment policy for even smaller but positive adjustment costs. Panels E and F of Figure 8 depict the total expected costs and the adjustment policy for adjustment costs of 0.1. Not surprisingly, smaller adjustment costs allow for substantially larger adjustments of the input mix. This, in turn, reduces the overall expected costs as depicted by Panel E.

Furthermore, we compute the value of management as the percent decrease of total production costs due to the active adjustment of inputs in face of small adjustment costs (.1 in this case). Panel A of Figure 8 depicts the value of management as a function of the capital to labor ratio and the interest rates. Panel B fixes the contemporaneous interest rate at .08 and depicts the value of management only as a function of the capital to labor ratio. In other words, Panel B presents a "slice" of the surface depicted in Panel A. By actively managing the input mix, managers are able to reduce production costs by 5 to over $30 \%$ relative to the no adjustments case. As evident from Figure 8, this effect is largest if the current input mix is furthest away from the optimum. However, even if the 
input mix is currently at the optimum, active management is able to substantially reduce overall costs. The optimal capital to labor ratio in the case of Panel B, for instance, is a little less then 2 , because wages are expected to grow while interest rates are expected to be mean reverting. Even if the input mix is optimal, however, active management results in cost savings of nearly $5 \%$ of overall production costs.

While the above estimated costs savings are based on a very specific set of model parameters, our overall conclusion regarding the ability of active management to add value does not. For example, Figure 9 depicts the value of management for different interest rates and wages assuming the starting input proportions are optimal. To produce this figure we eliminate the capital to labor ratio dimension from the three-dimensional state space. In doing so we choose the capital to labor ratio that is optimal given the cost of inputs on each grid point displayed. The overall shape of the figure is driven by our assumption that wages grow by a constant amount every year, while interest rates are mean reverting. This explains why the percent decrease of costs goes down as wages go up (i.e., the denominator increases). Nonetheless, it is apparent that regardless of the cost of capital - cost of labor combination, active management adds value even if the initial input mix is optimal.

Although, it has not been made explicit so far, the most important determinant of the above findings is the volatility of the interest rates. As mentioned above, we assume a Cox, Ingersoll, and Ross $(1980,1985)$ (CIR) model with parameters estimated by Chan, Karolyi, Longstaff, and Sanders (1992) (CKLS). Below we report the estimates of the value of management for various cost of capital volatilities. Panel A of Figure 10 depicts the value of management if the initial $\mathrm{K} / \mathrm{L}$ ratio is at the optimum. Panel B depicts the average value of management for all initial state variable values we investigate (i.e., capital to labor ratio between .3 and 4, and interest rates and wages between .01 and .1). Not surprisingly, the higher the volatility of the cost of capital, the higher the value of management, regardless of the starting point. If interest rates follow the CIR model with parameter estimates given by CKLS, the value of management is approximately $5 \%$ of total costs even if the initial $\mathrm{K} / \mathrm{L}$ ratio is at the optimum. On average, the value of management is $14 \%$ of total production costs. 
This finding has direct implications for the value of management and, in turn, the CEO compensation. Economies with very volatile costs of inputs present more challenges for managers and, therefore, more opportunity for them to add value. This conclusion is intuitive because historically economies subject to substantial government intervention, especially regarding the price of production inputs, have offered very low managerial compensation.

Even more important implication of our model is that higher adjustment costs reduce the opportunity of managers to add value. Figure 11 depicts the value of management for various levels of adjustment costs. Panel A depicts the value of management if the starting input mix is at the optimum. This presents a lower bound of the value of management for our parameters. Panel B depicts the average value of management for all starting input mixes studied. Both panels clearly indicate that adjustment costs have a substantial impact on the ability of management to add value. For instance, if the starting input mix is optimal, active management can reduce the total costs by nearly $5 \%$ if adjustment costs are low (i.e., .1). This ability to reduce costs goes down to $1.5 \%$ if adjustment costs are slightly higher (i.e., .9). This difference is even larger if we consider starting input mixes that are not optimal. It is not surprising that the ability of management to add value is higher in that case, but it is worth noting that the increase in adjustment costs has a relatively larger impact. For instance, if the starting mix is optimal, the value of management drops in half over the range of adjustment costs we consider. If we include all starting input mixes considered, including the ones away from the optimum, the value of management drops by nearly two-thirds over the same range of adjustment costs.

In summary, our analysis indicates that higher adjustment costs limit the ability of active management to add value. This effect is largest if the starting input mix is furthest away from the optimum. Put differently, economic environments with high adjustment costs, due to unionization, government regulation, or the nature of the production process, limit the ability of managers to add value. This, in turn, reduces the overall management compensation in such economies. 


\section{Summary and Direction for Future Work}

Most sources of management value are related either to product markets, production technology, or production inputs. To the extent that product markets are integrated globally and all firms have access to the same fundamental technology, the only source of management value potentially able to explain the cross-country variation in management compensation is the management of inputs. Put differently, while managing inputs is not the main process through which managers add value, it has the advantage of being unique to each economy or industry.

This is why we laid out above a simple model of the firm in which the value of management is determined mainly by the level of adjustment costs in the production function, as well as by the variability of the input prices. The model suggests that CEOs in countries with high adjustment costs, maybe arising from the nature of the production technology or from government or union restrictions, typically add little value to their firms. Similarly, in countries or industries with low variability in production input prices, for example arising from non-market determined wages and costs of capital, the value added from active management is minimal.

We view the model above as providing insight mainly into the value of management, or put differently, the scope for management compensation. The actual compensation received by a manager depends, of course, not only on the value (s)he adds to the company, but also on the supply of people with identical or similar skills.

We do however have some empirical evidence on the link between value-added and CEO compensation. Conyon and Murphy (2000) report that the median US CEO receives $1.48 \%$ of any increase in shareholder wealth compared with $0.25 \%$ in the UK. These differences could of course either arise from differences in production technologies and economic environments, as in our model, or from differences in the supply of managers in the two countries, which we haven't modeled. It would of course be of interest to explicitly model the supply of managers and their mobility, but we leave this important topic for future work.

To sum up, our model shows that the lower the costs of input adjustment, and the higher the volatility of input prices, the higher the value created by the management. Therefore, managers in countries and industries facing low constraints on input 
substitution are expected to command higher compensation. We would thus expect that, for example, in countries with a low degree of unionization and open capital markets, managers would command relatively high compensation. The positive relationship between input price volatility and the value of management suggests a real option interpretation of the manager: Active management can be viewed as a real option to make changes in the production plan. The higher the volatility of input prices the larger the value of this real option. 


\section{References}

Abowd, John and David Kaplan (1999), "Executive Compensation: Six Questions that Need Answering," Journal of Economic Perspectives, 13, 145-168.

Cadenillas, Abel, Jaksa Cvitanic, and Fernando Zapatero (2002), "Executive Stock Options with Effort Disutility and Choice of Volatility," Working Paper, Marshall School of Business, USC.

Chan, K.C., G.A. Karolyi, F.A. Longstaff and A.B. Sanders (1992), "An Empirical Comparison of Alternative Models of the Short-Term Interest Rate," Journal of Finance 47, 1209-1227.

Conyon, Martin J. and Kevin J. Murphy (2000), "The Prince and the Pauper? CEO Pay in the United States and the United Kingdom,” The Economics Journal, 110, F640-F671.

Conyon, M. and J. Schwalbach (1997), "European Differences in Executive Pay and Corporate Governance," Warwick Business School.

Cox, J.C., J.E. Ingersoll, and S.A. Ross (1985), “A Theory of the Term Structure of Interest Rates," Econometrica 53, 385-407.

Kaplan, S. (1994), "Top Executive Rewards and Firm Performance: A Comparison of Japan and the United States," Journal of Political Economy, 102, 510-546.

Kaplan, S. (1997), "Top Executive Incentives in Germany, Japan, and the US: A Comparison," Manuscript, University of Chicago.

Main, G. C. O'Reilly, and G. Crystal (1994), "Over Here and Over There: A Comparison of Top Executive Pay in the UK and the USA," Contributions to Labour Studies, 4, 115-127.

Murphy, Kevin J. (1999), "Executive Compensation," in Orley Ashenfelter and David Card (eds.), Handbook of Labor Economics, Vol. 3, North Holland.

Smith, C. and R. Watts (1992), "The Investment Opportunity Set and Corporate Financing, Dividend and Compensation Policies," Journal of Financial Economics, 32, 263-92.

Towers Perrin (2002), Worldwide Total Remuneration 2001-2002 
Figure 1: CEO Pay, Worldwide, 2001 (1,000 US\$)

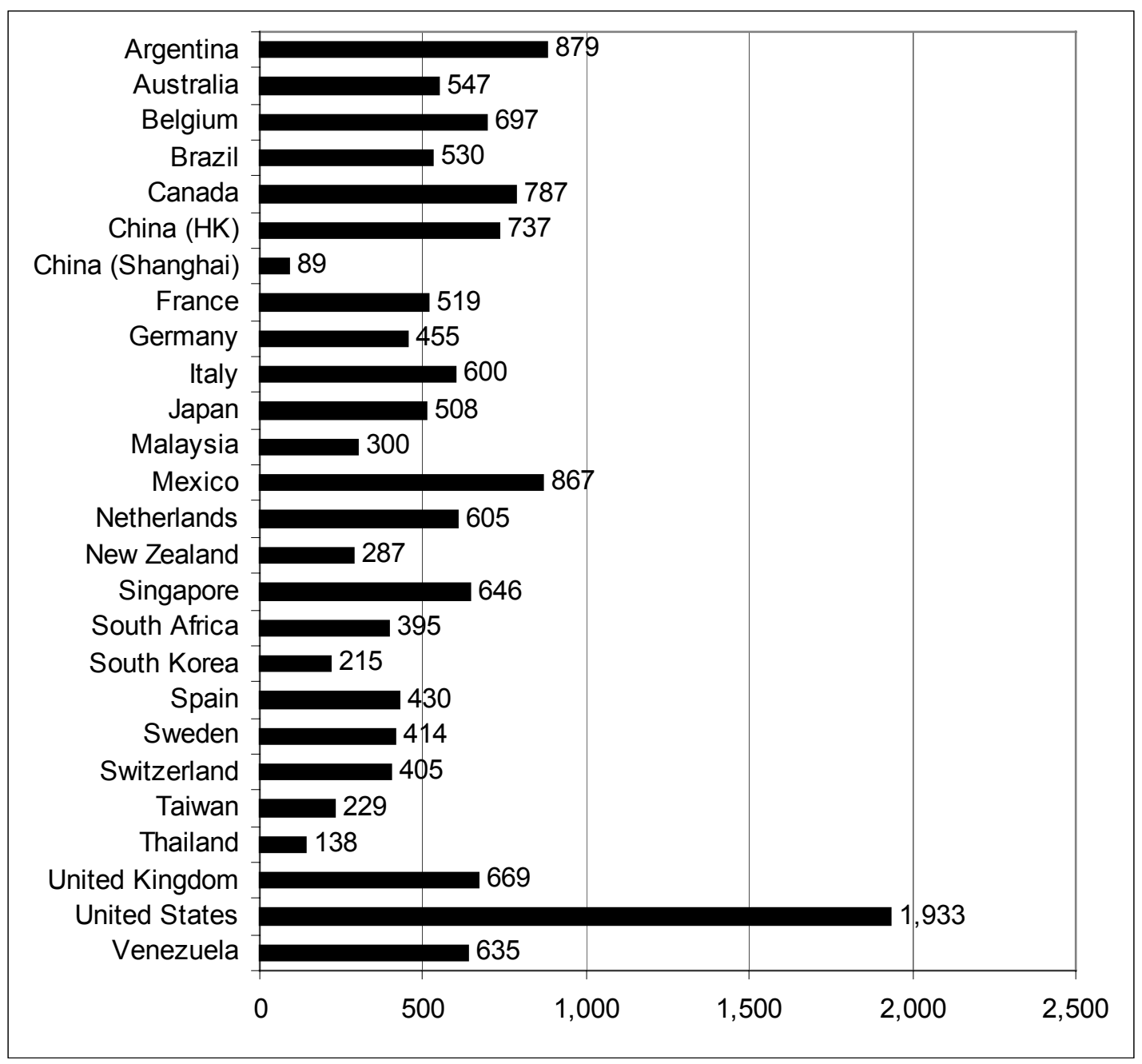

Notes to Figure: Data is from Towers Perrin's Worldwide Total Remuneration 20012002 study. CEO pay includes basic compensation, variable bonus, compulsory company contributions, voluntary company contributions, perquisites, and long-term incentives such as stock options and stock grants. 
Figure 2: CEO Pay, OECD, 1996, (PPP)

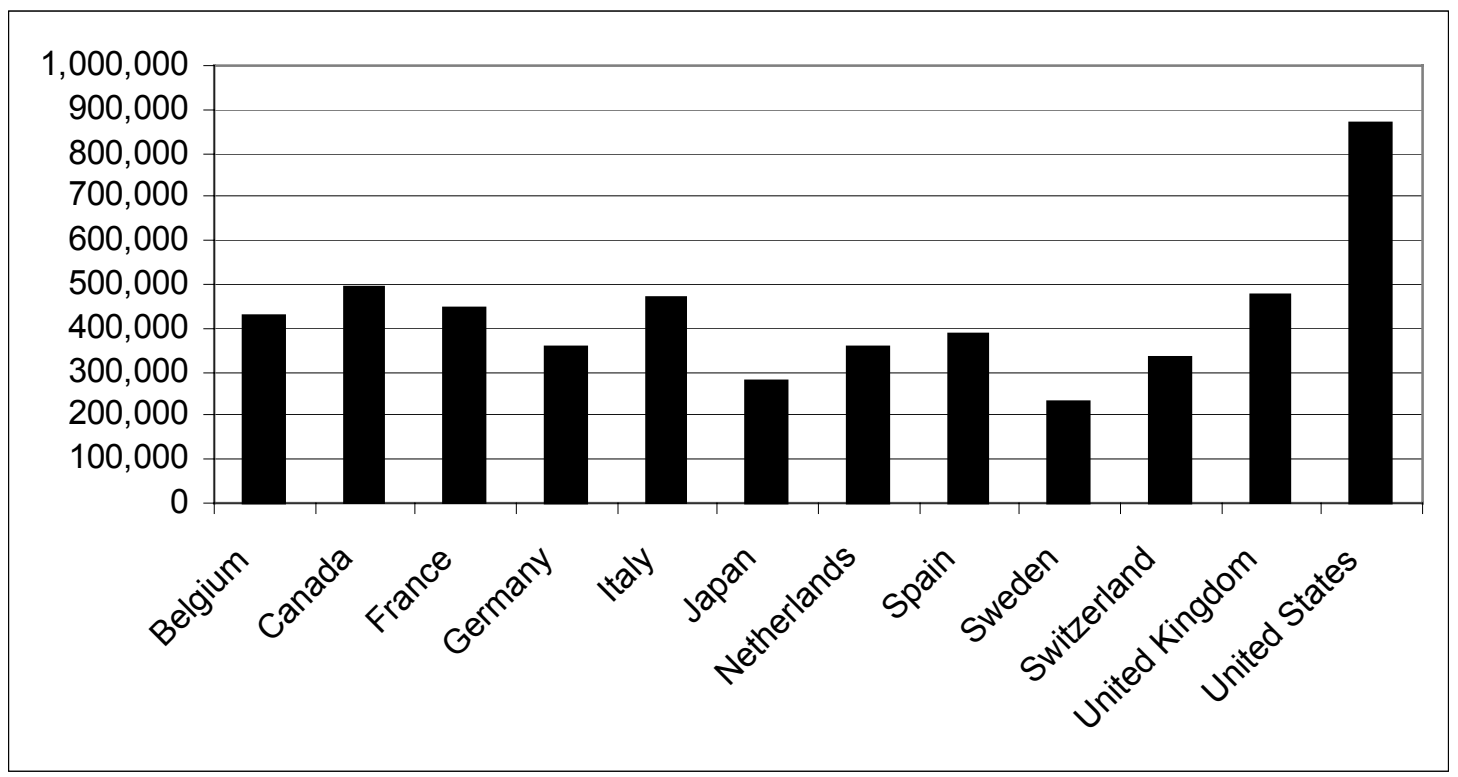

Notes to Figure: Data is from Abowd and Kaplan (1999) and reported at purchasing power parity (PPP).

Figure 3: Human Resource Manager Pay, OECD, 1996, (PPP)

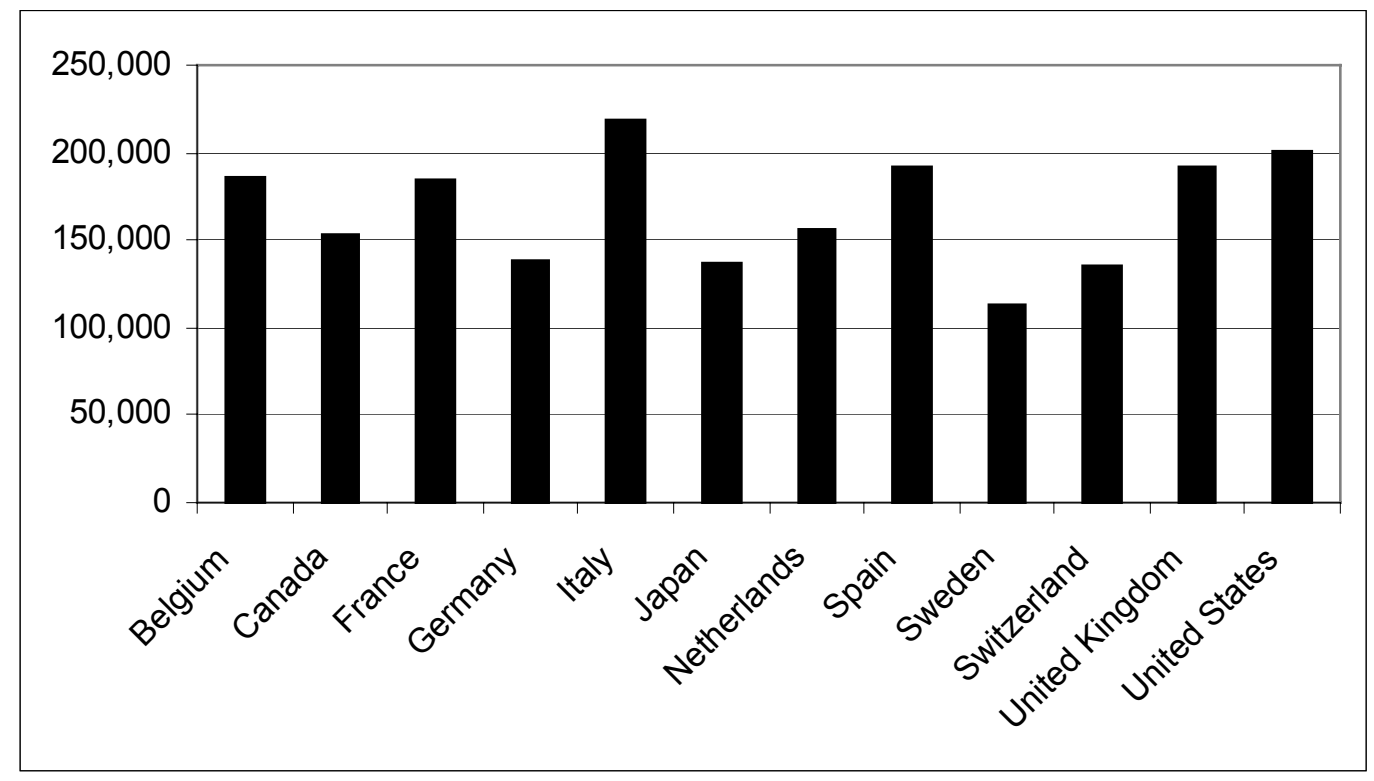

Notes to Figure: Data is from Abowd and Kaplan (1999) and reported at purchasing power parity (PPP). 
Figure 4: Manufacturing Operatives Pay, OECD, 1996, (PPP)

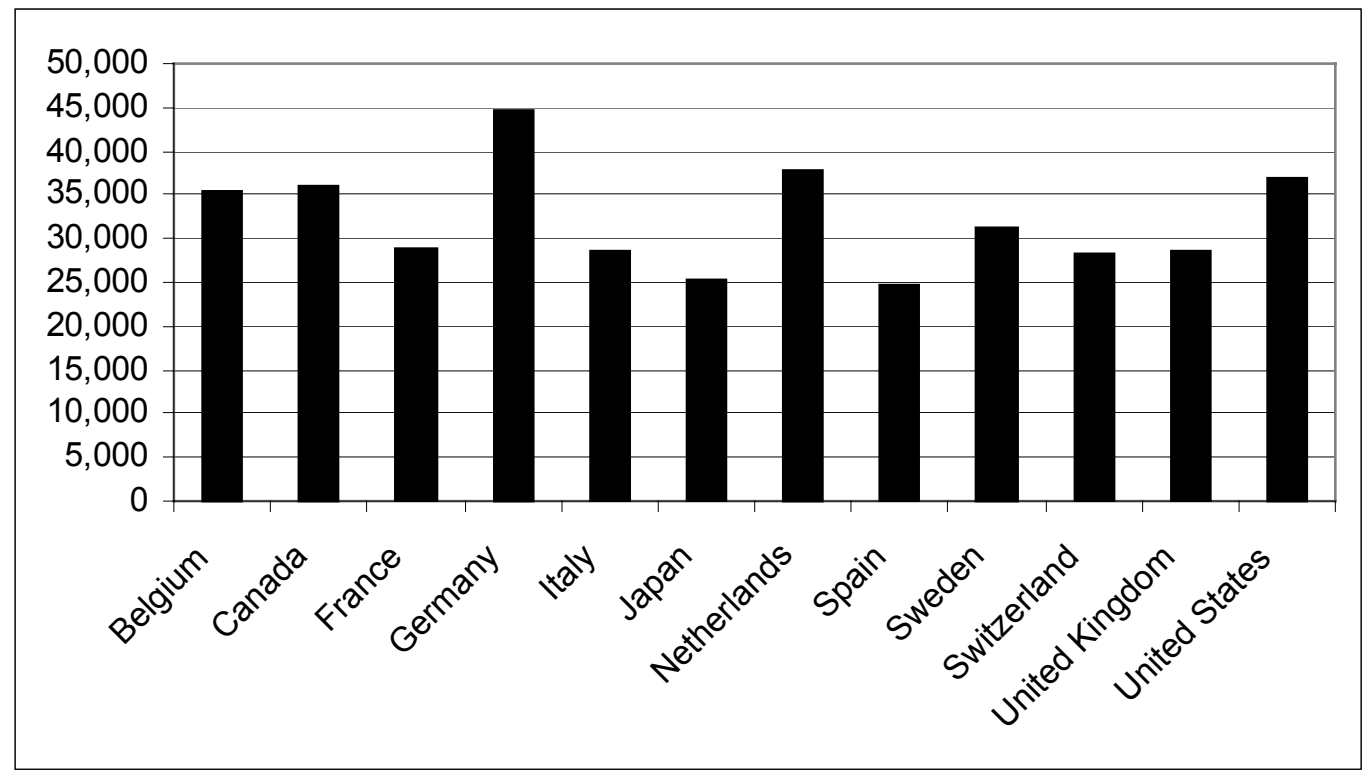

Notes to Figure: Data is from Abowd and Kaplan (1999) and reported at purchasing power parity (PPP).

Figure 5: CEO Pay After Taxes, OECD, 1996, PPP

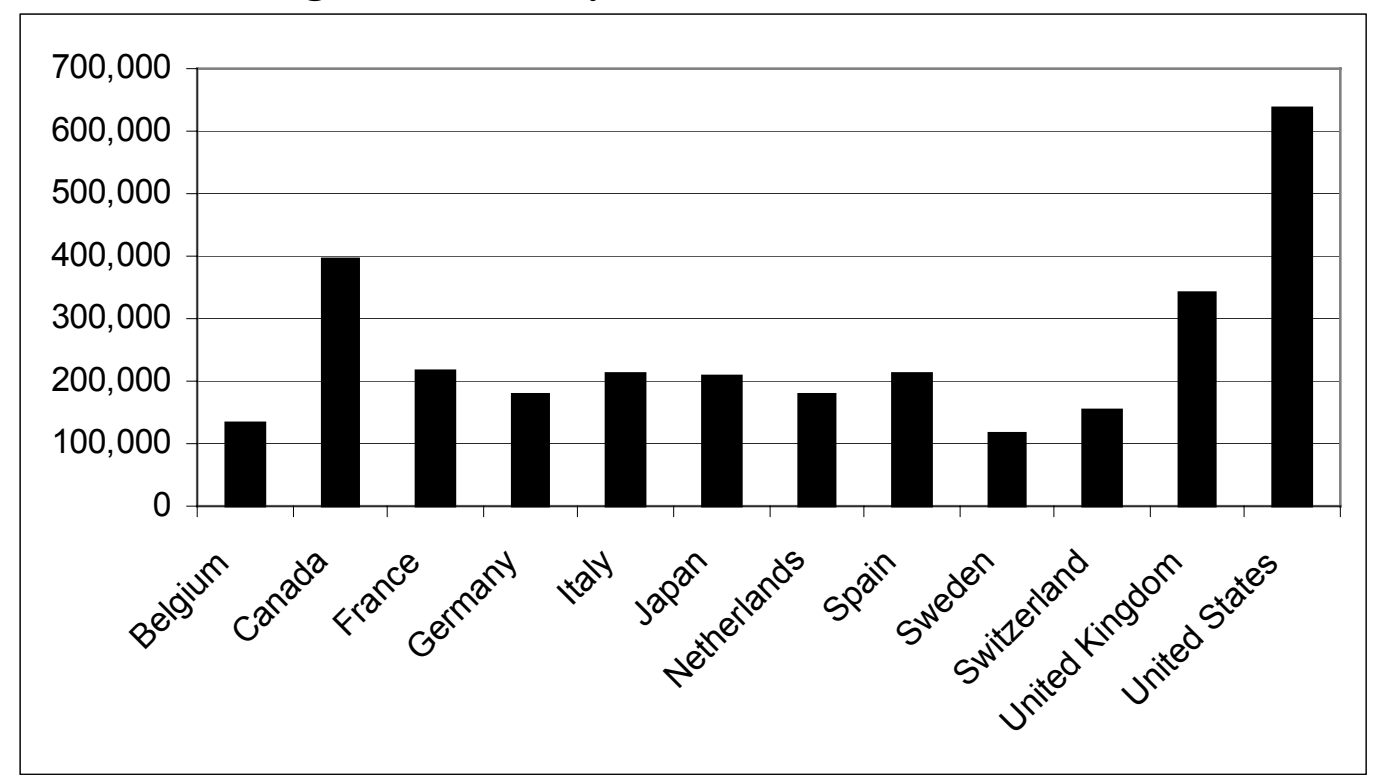

Notes to Figure: Data is from Abowd and Kaplan (1999) and reported at purchasing power parity (PPP). 
Figure 6: CEO Pay After Taxes, OECD, 1988, PPP

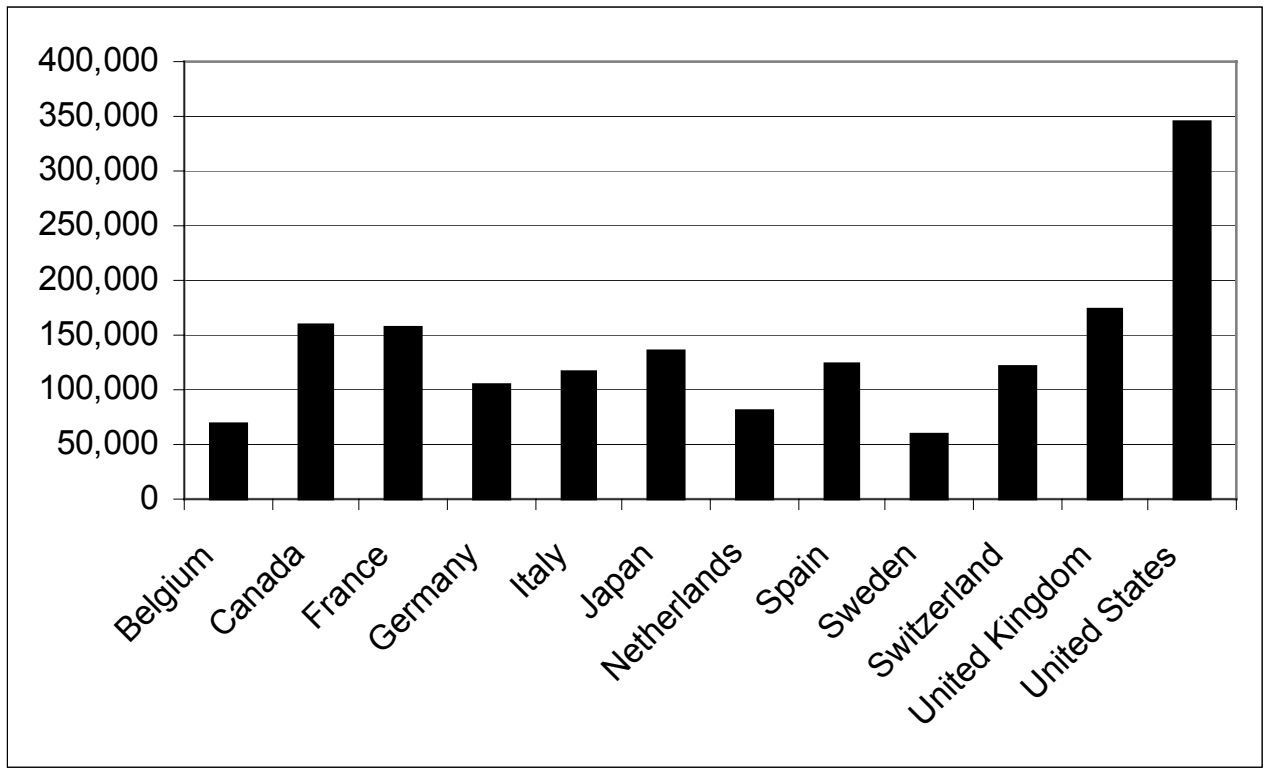

Notes to Figure: Data is from Abowd and Kaplan (1999) and reported at purchasing power parity (PPP). 


\section{Figure 7: Total Expected Cost and Optimal Policy with Adjustment Costs}

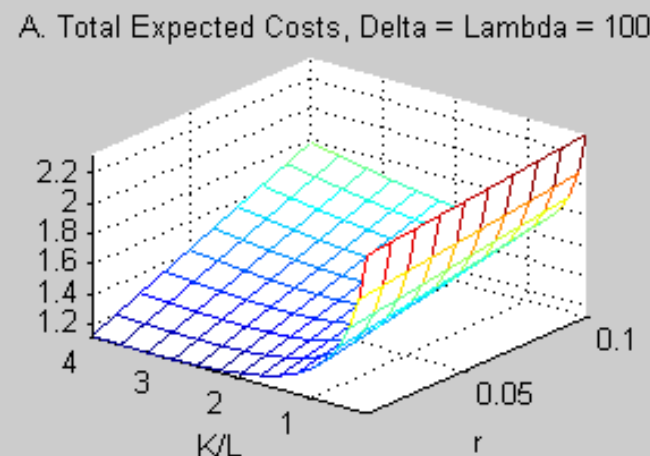

B. Adjustment Policy, Delta $=$ Lambda $=100$

C. Total Expected Costs, Delta $=$ Lambda $=1$

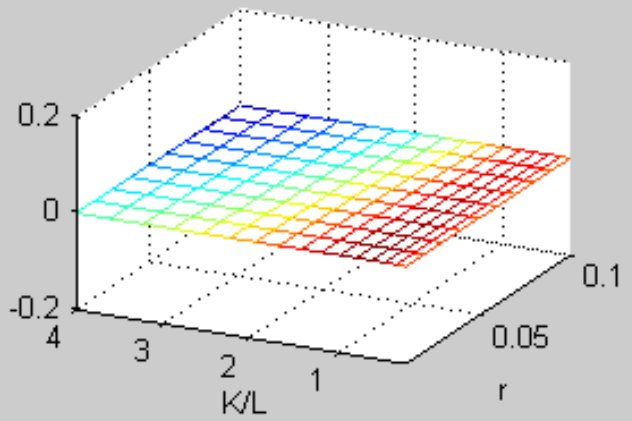

D. Adjustment Policy, Delta $=$ Lambda $=1$
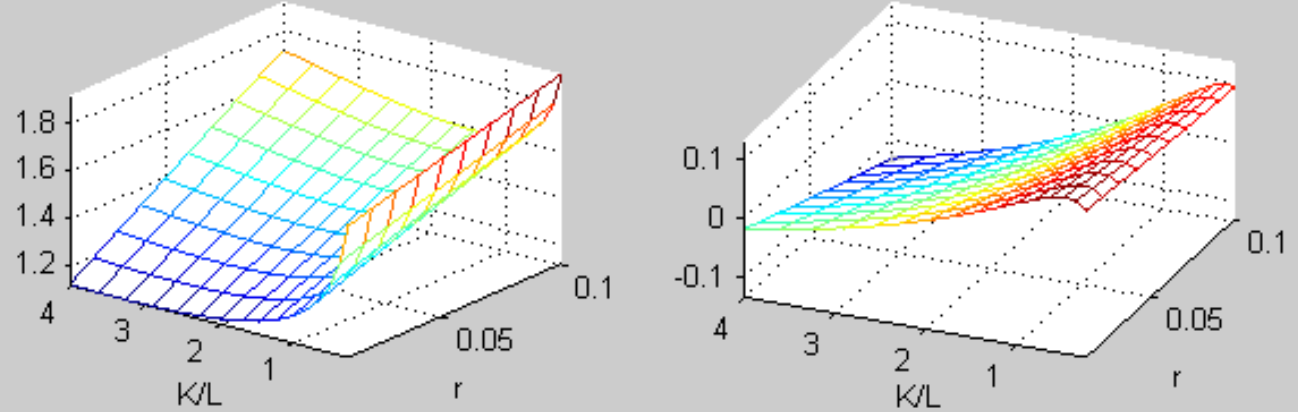

E. Total Expected Costs, Delta $=$ Lambda $=0.1$

F. Adjustment Policy, Delta $=$ Lambda $=0.1$
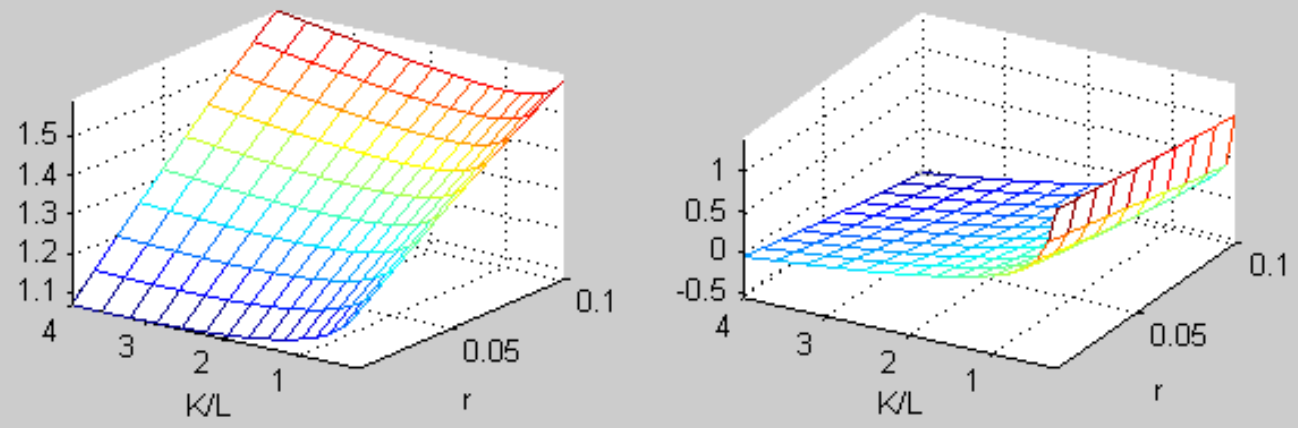

Notes to Figure: The figures depict the current capital to labor ratio, $K / L$, and the current interest rate, $R$, on the horizontal axes. All figures are depicted for wages $=.08$, although the actual solutions involves a full three-dimensional finite difference approximation and considers a large range for the current wages. The overall shape of the surfaces is very similar for all levels of wages. The adjustment policy is most aggressive and the total adjustment costs are smallest for low adjustment costs (e.g., Panels E and F). Not surprisingly, the total expected costs are largest when the current capital/labor ratio is away from the optimum for any positive adjustment costs. This effect is largest for high adjustment costs (e.g., Panels A and B). Panels D and F suggest that larger capital/labor ratio results in a reduction of the capital, and lower capital/labor ratio results in an 
increase of the capital. When the current capital is close to zero, the production function utilized here assumes there is a lot of labor employed. Thus, even small increases in capital results in very high decreases in labor. Because of this, for moderate adjustment costs (e.g. Panels $C$ and D), the level of adjustment of capital decreases for very low levels of capital. If the labor adjustment costs are even smaller, as is the case of Panels E and $\mathrm{F}$, then this phenomenon disappears and lower capital levels result in higher accumulation of capital. 
Figure 8: Total expected costs and adjustment policy for cost of adjustment of 0.1
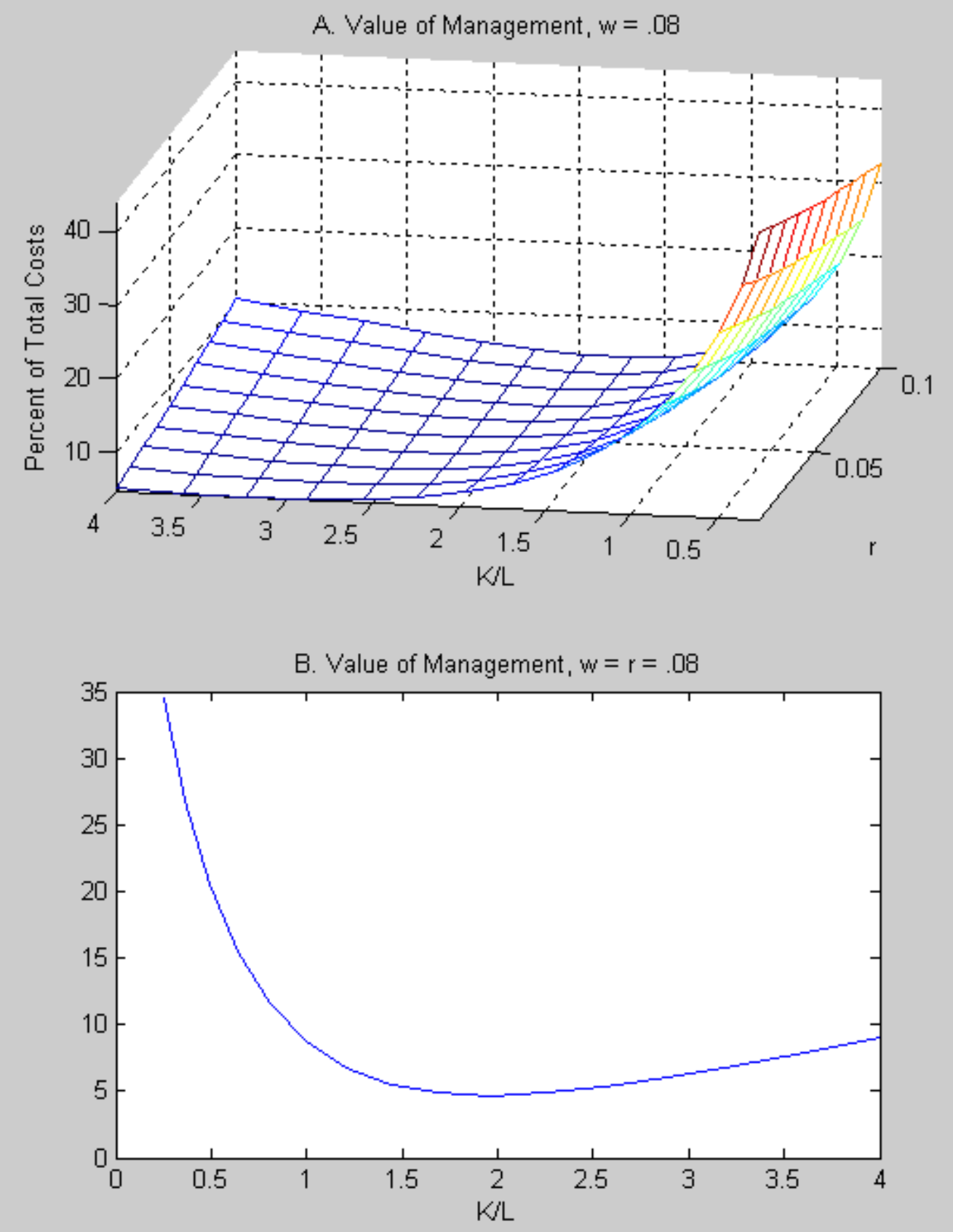

Notes to Figure: Panel A depicts the value of management as the percent reduction of total expected costs relative to a no adjustment policy. Panel D shows a slice of the percent decrease of costs if the current rate of return on capital is $8 \%$. Notice that even if the capital level is at the long-term optimum at the beginning, active management is able to reduce the costs of production by over $5 \%$ by adjusting the inputs. 


\section{Figure 9: Value of Management and Interest Rates}

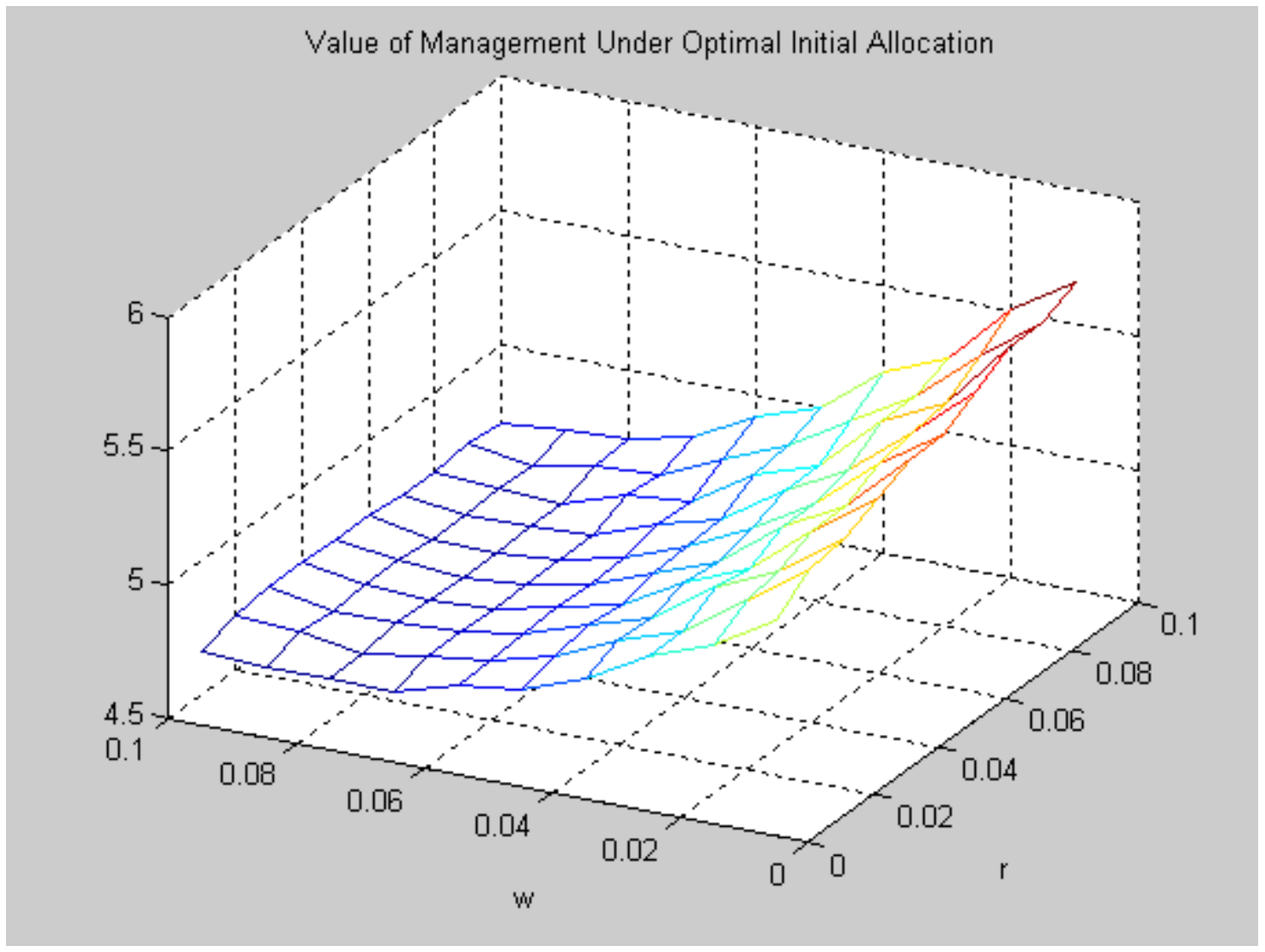

Notes to Figure: The figure depicts the value of management as a percent of total cost for various wages and interest rates assuming the starting capital to labor ratio is at the optimum. The overall shape of the figure is driven by our assumptions that wages are expected to grow at a constant rate while interest rates are mean reverting. 
Figure 10: Value of Management and Volatility of the Cost of Capital

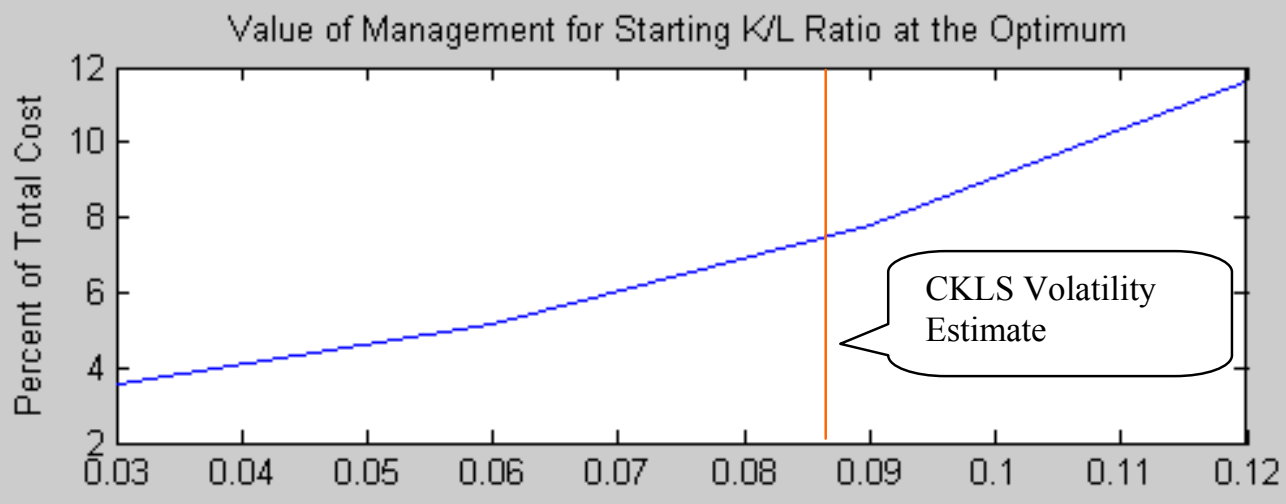

Average Value of Management for All Starting K/L Ratios Studied

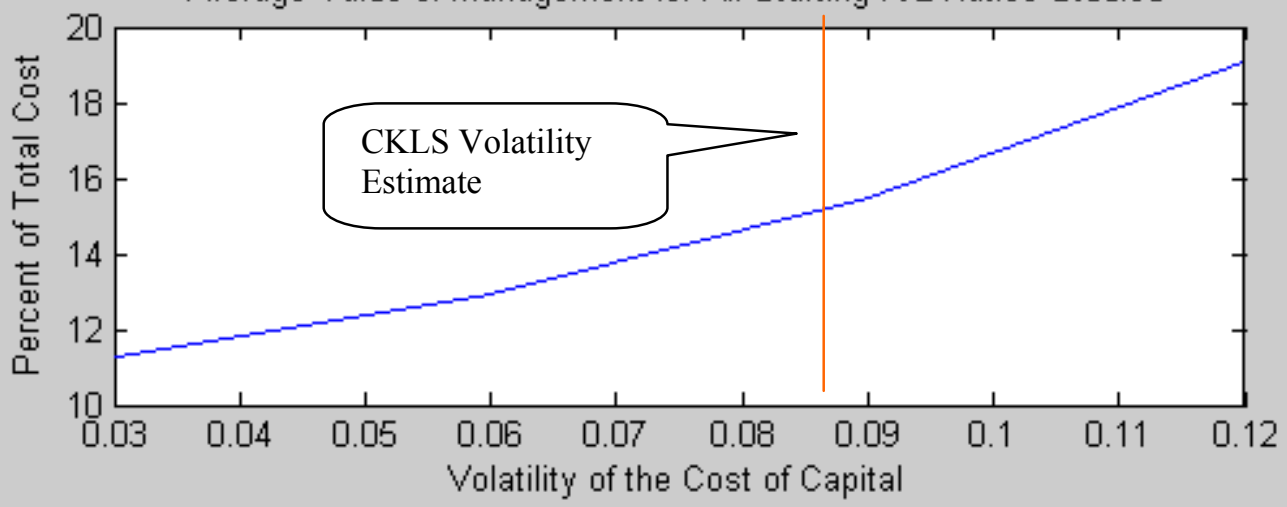

Notes to Figure: This figure depicts the value of management as a percent of total production costs for different levels of interest rate volatility. Panel A depicts the value of management assuming the starting input mix is optimal, while Panel B depicts the average value of management for all starting input combinations considered. As expected, the higher the volatility of the cost of capital, the higher the ability of management to add value. This effect is largest if the starting input mix is away from the optimum. 
Figure 11: Value of Management and Adjustment Costs

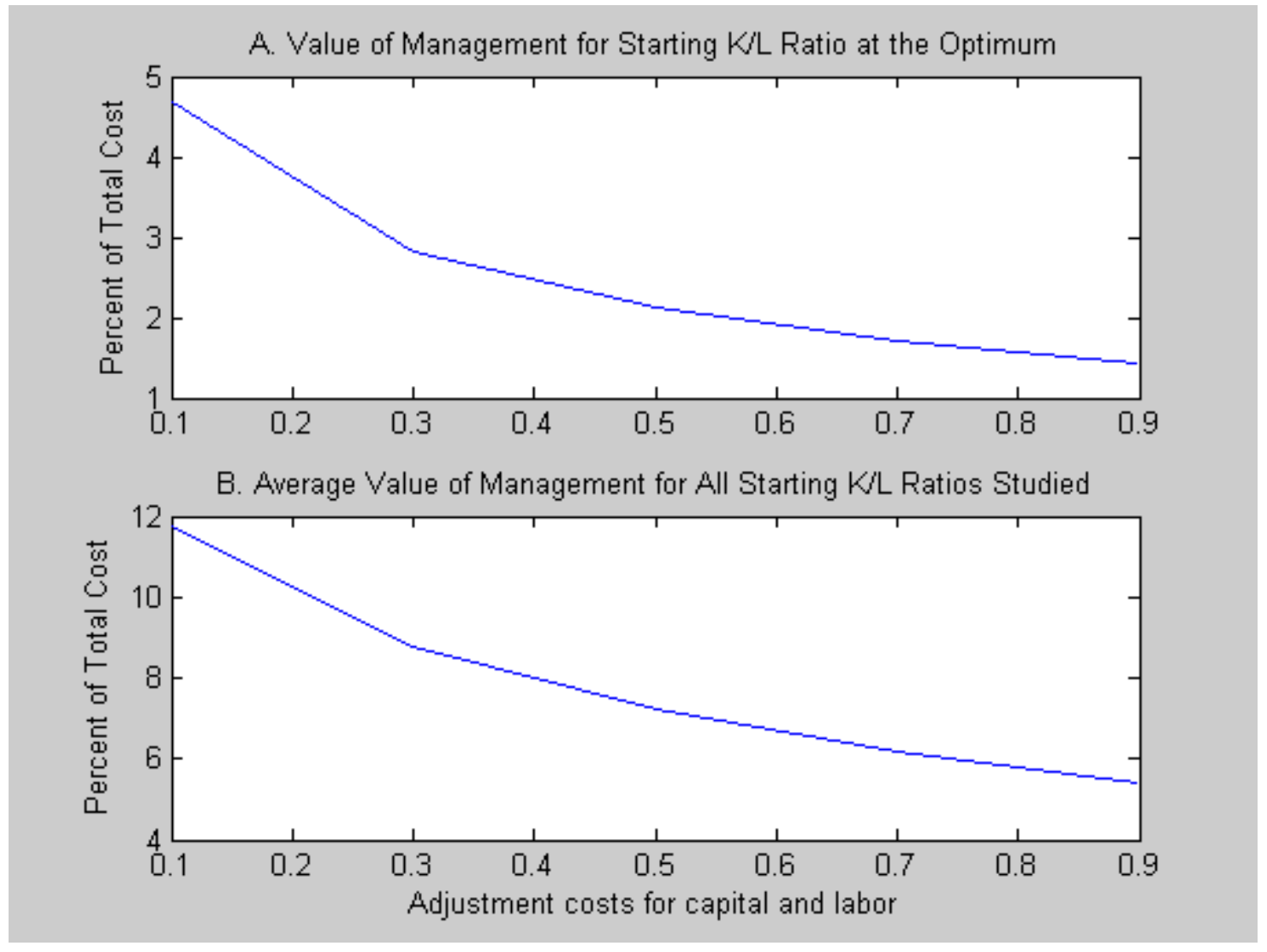

Notes to Figure: This figure depicts the value of management, as a percent of total cost, for different adjustment costs. Panel A depicts the value of management if the starting capital to labor ratio is optimal. In that case active management has the important role of adjusting the input mix if input prices change in the future. Panel B depicts the value of management for all starting capital to labor ratios considered in our analysis. Not surprisingly, including starting input mixes that are away from the optimum increases the average value of management. Furthermore, the impact of the adjustment costs and the ability of management to add value are higher for starting input mix away from the optimum. 